Article

\title{
Estimation of Energy Balance Components over a Drip-Irrigated Olive Orchard Using Thermal and Multispectral Cameras Placed on a Helicopter-Based Unmanned Aerial Vehicle (UAV)
}

\author{
Samuel Ortega-Farías ${ }^{1, *}$, Samuel Ortega-Salazar ${ }^{2}$, Tomas Poblete ${ }^{1}$, Ayse Kilic ${ }^{2}$, Richard Allen ${ }^{3}$, \\ Carlos Poblete-Echeverría ${ }^{4}$, Luis Ahumada-Orellana ${ }^{1}$, Mauricio Zuñiga ${ }^{1}$ and Daniel Sepúlveda ${ }^{1}$ \\ 1 Centro de Investigación y Transferencia en Riego y Agroclimatología (CITRA) and Research program on \\ Adaptation of Agriculture to Climate Change (A2C2), Universidad de Talca, Casilla 747, Talca 3460000, \\ Chile; tpobletec@alumnos.utalca.cl (T.P.); lahumada@utalca.cl (L.A.-O.); \\ mzuniga_sanchez@hotmail.com (M.Z.); dsepulveda18@gmail.com (D.S.) \\ 2 School of Natural Resources and Civil Engineering, University of Nebraska-Lincoln, 311 Hardin Hall, \\ 3310 Holdrege Street, Lincoln, NE 68588, USA; sortegas88@hotmail.com (S.O.-S.); akilic@unl.edu (A.K.) \\ 3 Biological and Agricultural Engineering and Civil Engineering, Research and Ext. Center, \\ University of Idaho, Kimberly, Moscow, ID 83844, USA; rallen@uidaho.edu \\ 4 Escuela de Agronomía, Pontificia Universidad Católica de Valparaíso, Quillota 2260000, Chile; \\ carlos.poblete@pucv.cl \\ * Correspondence: sortega@utalca.cl; Tel.: +56-71-220-0426
}

Academic Editors: Mutlu Ozdogan, Jose Moreno, Clement Atzberger and Prasad S. Thenkabail Received: 23 February 2016; Accepted: 1 August 2016; Published: 8 August 2016

\begin{abstract}
A field experiment was carried out to implement a remote sensing energy balance (RSEB) algorithm for estimating the incoming solar radiation (Rsi), net radiation ( $R n)$, sensible heat flux $(H)$, soil heat flux $(\mathrm{G})$ and latent heat flux (LE) over a drip-irrigated olive (cv. Arbequina) orchard located in the Pencahue Valley, Maule Region, Chile $\left(35^{\circ} 25^{\prime}\right.$ S; $71^{\circ} 44^{\prime} \mathrm{W} ; 90 \mathrm{~m}$ above sea level). For this study, a helicopter-based unmanned aerial vehicle (UAV) was equipped with multispectral and infrared thermal cameras to obtain simultaneously the normalized difference vegetation index (NDVI) and surface temperature $\left(\mathrm{T}_{\text {surface }}\right)$ at very high resolution $(6 \mathrm{~cm} \times 6 \mathrm{~cm})$. Meteorological variables and surface energy balance components were measured at the time of the UAV overpass (near solar noon). The performance of the RSEB algorithm was evaluated using measurements of $\mathrm{H}$ and LE obtained from an eddy correlation system. In addition, estimated values of Rsi and Rn were compared with ground-truth measurements from a four-way net radiometer while those of G were compared with soil heat flux based on flux plates. Results indicated that RSEB algorithm estimated LE and $\mathrm{H}$ with errors of $7 \%$ and $5 \%$, respectively. Values of the root mean squared error (RMSE) and mean absolute error (MAE) for LE were 50 and $43 \mathrm{~W} \mathrm{~m}^{-2}$ while those for $\mathrm{H}$ were 56 and $46 \mathrm{~W} \mathrm{~m}^{-2}$, respectively. Finally, the RSEB algorithm computed Rsi, Rn and G with error less than $5 \%$ and with values of RMSE and MAE less than $38 \mathrm{~W} \mathrm{~m}^{-2}$. Results demonstrated that multispectral and thermal cameras placed on an UAV could provide an excellent tool to evaluate the intra-orchard spatial variability of Rn, G, H, LE, NDVI and $\mathrm{T}_{\text {surface }}$ over the tree canopy and soil surface between rows.
\end{abstract}

Keywords: evapotranspiration; irrigation; remote sensing; energy balance; olive orchard; UAV

\section{Introduction}

Olive orchards have increased significantly in Chile during the last decade, and water scarcity has become the main limitation to maintain olive oil production [1]. Studies indicate that Chile will face a significant reduction in rainfall of $20 \%-40 \%$ in the near future due to global climate change [2]. 
Under these conditions, sophisticated irrigation water management will be required to optimize water productivity (oil production per unit of consumed water, $\mathrm{kg} \mathrm{m}^{-3}$ ) and to maintain sufficient levels of yield and quality $[3,4]$. To achieve these targets, it is necessary to have a reliable method to quantify the olive water requirements and actual evapotranspiration (ETa). Traditional methods employ the ETo-crop coefficient approach $(\mathrm{ETa}=\mathrm{ETo} \times \mathrm{Kc}$, where ETo is the reference evapotranspiration $\left(\mathrm{mm} \mathrm{day}^{-1}\right)$ and $\mathrm{Kc}_{\mathrm{c}}$ is the crop coefficient) $[5,6]$. The accurate estimate of ETa or latent heat flux (LE) is an important factor for establishing irrigation strategies such as regulated deficit irrigation (RDI), which has been successfully applied on olive orchards to increase water productivity and olive oil quality [7-10]. In addition, Cohen et al. [11] and Ortega-Farias et al. [12] indicated that the site-specific irrigation management (SSIM) can be used as a technical tool to improve water productivity. In that case, SSIM characterizes the effect of intra- and inter-field spatial variability of soil and canopy vigor on the estimation of ETa and irrigation scheduling (irrigation frequency and timing).

Carrasco-Benavides et al. $[13,14]$ and Samani et al. [15] have demonstrated that remote sensing energy balance (RSEB) models can be used to estimate the spatial variability of LE or ETa over sparse canopies such as orchards and vineyards. Several RSEB algorithms that vary in complexity compute $\mathrm{ETa}\left(\mathrm{mm} \mathrm{h}^{-1}\right)$ as residual from the energy balance (EB) equation [16-23]:

$$
\mathrm{LE}=\mathrm{Rn}-\mathrm{H}-\mathrm{G}=\mathrm{ETa} \frac{\lambda \rho_{\mathrm{w}}}{3600}
$$

where LE is the latent heat flux $\left(\mathrm{W} \mathrm{m}^{-2}\right)$; $\mathrm{Rn}$ is the net radiation $\left(\mathrm{W} \mathrm{m}^{-2}\right)$; $\mathrm{G}$ is the soil heat flux $\left(\mathrm{W} \mathrm{m}{ }^{-2}\right) ; \mathrm{H}$ is the sensible heat flux $\left(\mathrm{W} \mathrm{m}^{-2}\right) ; \lambda$ is the latent heat of vaporization $\left(\mathrm{J} \mathrm{kg}^{-1}\right) ; \rho_{\mathrm{W}}$ is the density of water $\left(\cong 1000 \mathrm{~kg} \mathrm{~m}^{-3}\right)$; and 3600 converts from seconds to hours. Values of LE, Rn, G and H are estimated at the time of the satellite overpass.

RSEB algorithms have been found to be useful to account for the spatial and seasonal variability of ETa at regional and field scales when using satellite platforms like Landsat (8, 7 and 5) and ASTER [18,24,25]. Main limitations of current satellite platforms for practical application of RDI and SSIM, especially in heterogeneous canopies such as orchards and vineyards, are the lack of fine spatial resolution and real-time data at the field and sub-field scales [26,27]. Berni et al. [28,29] suggested that the two critical limitations for using current satellite sensors in real-time crop management are the lack of imagery having optimum spatial and spectral resolution and unfavorable revisit times for many crop stress-detection applications. In addition, Matese et al. [30] indicated that low-resolution images of traditional acquisition platforms fail to represent much of the intra-vineyard variability that is a key for application of the site-specific management (precision viticulture) of heterogeneous vineyards.

Canopy covers of commercial olive orchards are generally incomplete as a result of the canopy geometry that depends on canopy size, leaf area index, and plant density. The canopy training system and associated canopy geometry may affect significantly the partitioning of Rn into H, LE or G. Ortega-Farías and López-Olivari [31] found H generated at the soil surface to play a key role in the estimation of LE as a residual from EB equation for a drip-irrigated orchard having low values of leaf area index $\left(\mathrm{LAI}=1.32 \mathrm{~m}^{2} \mathrm{~m}^{-2}\right)$, wetted area $(\mathrm{Aw}=4.5 \%)$ and fractional cover $(\mathrm{fr}=0.31)$. In regards to the orchard water requirements, good knowledge of the effect of intra-orchard spatial variability on the partitioning of Rn into $\mathrm{H}$ and $\mathrm{G}$ is necessary to improve the estimation of LE when using RSEB models. In addition, it is important to indicate that the current spatial resolutions of the thermal-based satellite platforms, which are $30 \mathrm{~m}$ or greater, introduce uncertainty to the quantification of LE or ET for heterogeneous canopies, where $\mathrm{H}$ generated at the soil surface between rows can be the primary component of the EB equation [1].

Modern optical remote sensors aboard an UAV provide the basis for the generation of very high spatial resolution images that can be used as inputs in the RSEB algorithms to estimate spatial variability of energy balance components. On this subject, multispectral and thermal sensors placed on an UAV could be a useful tool to advance our knowledge about the effect of intra-orchard spatial variability on the partitioning of Rn into G, H and LE over olive orchards whose row spacing range 
from 1 to $8 \mathrm{~m}$. Thus, the main objective of this research was to implement a remote sensing energy balance (RSEB) algorithm to estimate the incoming solar radiation (Rsi), net radiation (Rn), sensible heat $(\mathrm{H})$, soil heat $(\mathrm{G})$ and latent heat (LE) over a drip-irrigated olive orchard using multispectral and thermal cameras placed on a helicopter-based UAV.

\section{Material and Methods}

\subsection{Study Site Description}

Flight campaigns collecting measurements of energy balance components and climatic variables were carried out during February and March 2014 on a flat and relatively uniform olive orchard located in the Pencahue Valley, Región del Maule, Chile ( $35^{\circ} 23^{\prime} \mathrm{S} ; 71^{\circ} 44^{\prime} \mathrm{W} ; 96 \mathrm{~m}$. above sea level). The climate of the Pencahue Valley is a typical Mediterranean semiarid with a daily temperature equal to $14.8^{\circ} \mathrm{C}$ from September to May. The historical average annual rainfall in the region is about $602 \mathrm{~mm}$, falling mainly during the winter months (May to September). The summer period (December to February) is usually hot and dry (3.5\% of annual rainfall) while the spring period (September to November) is wet (16\% of annual rainfall).

The experiment was conducted on a drip-irrigated commercial young olive orchard (cv. Arbequina) cultivated for oil production (Figure 1a). The olive trees were planted at high density (5.0 $\mathrm{m}$ between row and $1.5 \mathrm{~m}$ between trees) with north-south orientation and trained on a triangular hedgerow system (similar to a monocone system) with a tree height (h) of $3.2 \mathrm{~m}$ and canopy width (cw) of $1.55 \mathrm{~m}$. The soil at the experimental site (Figure 1) is classified as Quepo series (Vertisol, family fine, thermic Xeric Apiaquerts) with a clay loam texture. The bulk density was $1.54 \mathrm{~g} \mathrm{~cm}^{-3}$ over the effective rooting depth of $0-60 \mathrm{~cm}$, and volumetric water content at field capacity and wilting point were 0.33 and $0.19 \mathrm{~m}^{3} \mathrm{~m}^{-3}$, respectively.

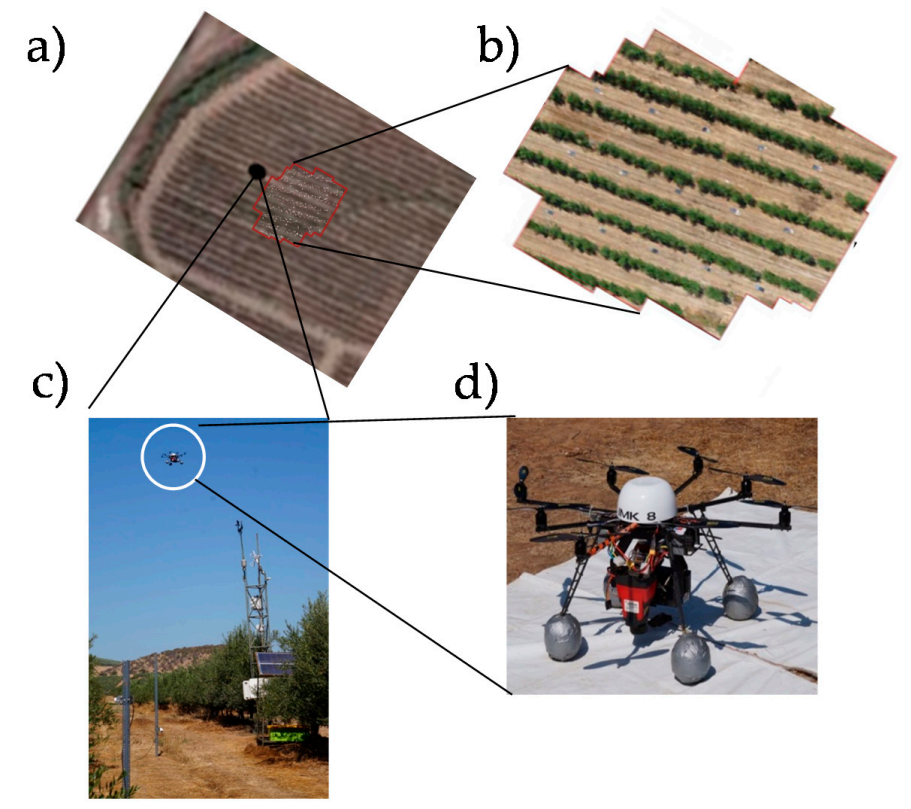

Figure 1. Experimental Site showing: (a) the location of eddy correlation (EC) system; (b) experimental site; (c) helicopter-based unmanned aerial vehicle (UAV) equipped with multispectral and infrared thermal cameras flying over an EC system installed over a drip-irrigated olive orchard; and (d) helicopter-based UAV.

To evaluate the impacts of irrigation management, the midday stem water potential ( $\Psi x)$ was monitored at the time of the UAV overpass using a pressure chamber (PMS instruments, model 600, Albany, OR, USA). This was done using 12 fully expanded leaves wrapped in aluminum foil and 
encased in plastic bags for at least $2 \mathrm{~h}$ before the measurements [8]. The leaf area index (LAI) was measured weekly in 8 olive trees during the study periods using a plant canopy analyzer (LAI-2000, LI-COR, Lincoln, NE, USA) which was calibrated according to [31].

\subsection{Measurements of Energy Balance and Climatic Data}

A tower of $5.5 \mathrm{~m}$ high was installed to measure both surface energy balance components and climatic variables (Figure 1c). The latent heat flux (LE) and sensible heat flux $(\mathrm{H})$ were measured using an eddy covariance system (EC) system oriented towards the predominant wind direction (south-east). The upwind fetch of the prevailing wind direction was about $500 \mathrm{~m}$ (for footprint analysis, see [1,31]). The EC consisted of a fast response open-path infrared gas analyzer (LI-7500 IRGA; LI-COR, Inc., Lincoln, NE, USA) and a three-dimensional sonic anemometer (CSAT3, Campbell Sci., Logan, UT, USA). $\mathrm{LE}$ and $\mathrm{H}$ measurements were made at $10 \mathrm{~Hz}$, and means, standard deviations, and covariances were calculated over 15-min periods. Raw data of $\mathrm{H}$ and LE were post-processed considering corrections for air density [32], sonic temperature [33] and coordinate rotation [34]. During quality control, the energy balance closure was estimated using the ratio $(\mathrm{Cr})$ of turbulent fluxes $(\mathrm{H}+\mathrm{LE})$ to available energy $(\mathrm{Rn}-\mathrm{G})$. When daily values of $\mathrm{Cr}$ were outside the range of 0.8 and 1.2 , the entire day was excluded to reduce the uncertainty associated with errors in the LE and H measurements [35]. Assuming that the measurements of $\mathrm{Rn}$ and $\mathrm{G}$ were representative of the available energy in the olive orchard, the fluxes of $\mathrm{H}$ and $\mathrm{LE}$ for remaining data were forced to close the energy balance using the Bowen ratio approach [1,36-38]:

$$
\begin{aligned}
& \mathrm{LEB}=\frac{\mathrm{Rn}-\mathrm{G}}{1+\beta} \\
& \mathrm{HB}=\frac{\mathrm{Rn}-\mathrm{G}}{1+\beta^{-1}}
\end{aligned}
$$

where $\beta(=\mathrm{H} / \mathrm{LE})$ is the Bowen ratio (dimensionless).

Net radiation ( $\mathrm{Rn}$ ), and incoming (Rsi) and outgoing (Rso) solar radiation were measured with a four-way net radiometer (CNR1, Kipp\&Zonen Inc., Delft, The Netherlands). Wind speed (u) and wind direction $(\mathrm{w})$ were monitored by a cup anemometer and a wind vane (03101-5, Young, MI, USA) and precipitation (Pp) was measured by a rain gauge (A730RAIN, Adcon Telemetry, Austria). Air temperature $\left(\mathrm{T}_{\mathrm{a}}\right)$ and relative humidity $(\mathrm{RH})$ were measured using a Vaisala probe (model HMP45C). In the tower, sensors of $\mathrm{u}, \mathrm{w}, \mathrm{Pp}, \mathrm{T}_{\mathrm{a}}, \mathrm{RH}, \mathrm{Rn}, \mathrm{Rsi}$, and Rso were installed at $5.5 \mathrm{~m}$ above the soil surface. A mobile tower with two CNR1 was also used to weekly measure canopy and soil albedos.

Soil heat flux $(\mathrm{G})$ was estimated using eight flux plates installed on either side of the rows, with 4 sites placed inter-row and 4 placed within rows of trees. This arrangement took into account the shading effects by trees during the course of the day. The flux plates of constant thermal conductivity (HFT3, Campbell Sci., Logan, UT, USA) were placed at a $0.08 \mathrm{~m}$ depth. Two averaging thermocouple probes (TCAV, Campbell Sci., Logan, UT, USA) for measuring soil temperature $\left(\mathrm{T}_{\text {soil }}\right)$ were installed above each flux plate at depths of 0.02 and $0.06 \mathrm{~m}$. Thermocouple probe signals were recorded at 15-min intervals on an electronic datalogger (CR3000, Campbell Sci, Logan, UT, USA). At each position, the soil heat flux was calculated by adding the measured flux at $0.08 \mathrm{~m}$ to the heat stored (S) in the layer above the heat flux plates [31]. All eight values for $G$ were averaged during energy balance closure analysis.

\subsection{Thermal and Multispectral Images Acquisition and Processing}

For the drip-irrigated olive orchard, thermal and multispectral images were acquired from days of year (DOY) 58 to 80 using a helicopter-based UAV system equipped with multispectral and infrared thermal cameras (Figure 1d). The UAV system used eight propellers for propulsion and GPS-based, preprogrammed control. The cameras were controlled by an autopilot computer program to take photographs at user-selected waypoints to ensure complete coverage of the field. To minimize the shading effect of the cover, images were acquired around midday under clear sky conditions (Table 1). 
The flight height was configured at $60 \mathrm{~m}$ above ground level. This height allowed obtaining imagery at $3.3 \mathrm{~cm}$ and $6 \mathrm{~cm}$ spatial resolution in multispectral and thermal regions, respectively. A total of 10 images (dates) were available following filtering of images to remove those impacted by instrumental problems (based on $\mathrm{Cr}$ ) and adverse meteorological conditions, especially with values of wind speed $u$ $>3.0 \mathrm{~m} \mathrm{~s}^{-1}$.

Table 1. Meteorological conditions at the time of UAV overpass during the 2014 study period.

\begin{tabular}{ccccccc}
\hline Flight Date & Flight Time $^{*}$ & $\mathbf{R s i}$ & $\mathbf{T}_{\mathbf{a}}$ & $\mathbf{R H}$ & $\mathbf{u}$ & $\mathbf{V P D}$ \\
\hline $\mathbf{( D O Y )}$ & $\mathbf{( h h : m m )}$ & $\mathbf{( W ~ m}^{-\mathbf{2}} \mathbf{)}$ & $\mathbf{(} \mathbf{C}^{\circ}$ & $\mathbf{( \% )}$ & $\left.\mathbf{( m ~ s}^{-\mathbf{1}}\right)$ & $\mathbf{( k P a )}$ \\
\hline 58 & $12: 46$ & 901 & 24.7 & 37.3 & 1.1 & 1.2 \\
59 & $12: 08$ & 892 & 22.9 & 38.4 & 1.5 & 1.1 \\
62 & $12: 09$ & 856 & 20.9 & 54.2 & 1.9 & 1.3 \\
64 & $12: 05$ & 833 & 22.8 & 50.0 & 1.5 & 1.4 \\
65 & $11: 56$ & 876 & 22.4 & 38.5 & 1.5 & 1.0 \\
66 & $12: 08$ & 857 & 23.1 & 39.4 & 2.7 & 1.1 \\
69 & $12: 08$ & 879 & 23.1 & 28.4 & 2.1 & 0.8 \\
73 & $12: 38$ & 839 & 21.1 & 50.8 & 1.8 & 1.3 \\
74 & $12: 49$ & 834 & 22.3 & 46.5 & 1.4 & 1.3 \\
80 & $12: 40$ & 801 & 18.1 & 40.8 & 1.0 & 0.9 \\
& Mean & $857( \pm 31)$ & $22.1( \pm 1.8)$ & $42.4( \pm 7.8)$ & $1.6( \pm 0.5)$ & $1.1( \pm 0.2)$ \\
\hline
\end{tabular}

* = local time (near solar noon); $\mathrm{Rsi}=$ incoming solar radiation; $\mathrm{T}_{\mathrm{a}}=$ air temperature; $\mathrm{RH}=$ relative humidity; $\mathrm{VPD}=$ vapor pressure deficit; $\mathrm{u}=$ wind speed.

The multispectral camera (Mini MCA-6, Tetracam, Inc., Chatsworth, CA, USA) was configured with 6 individual sensors in the VIS-NIR spectral range at 530, 550, 570, 670, 700 and $800 \mathrm{~nm}$, respectively. Image resolution was $1280 \times 1024$ pixels with 10-bit radiometric resolution and optics focal length of $9.6 \mathrm{~mm}$. Images acquired with the Mini MCA-6 camera were preprocessed using the image handling application Pixel Wrench 2 (Tetracam Inc.) to produce multi-page TIF files. Radiometric calibration was performed using images of a spectralon white panel as a reference, which was acquired on the ground with the mini MCA-6 at the beginning and end of each flight [28]. The multispectral images were radiometrically corrected to convert the digital number of each pixel (brightness value) first into spectral radiance and then into reflectance as described by [39]. Afterwards, normalized difference vegetation index (NDVI) was computed by the traditional equation proposed by [40]:

$$
\mathrm{NDVI}=\frac{\mathrm{NIR}-\mathrm{RED}}{\mathrm{NIR}+\mathrm{RED}}
$$

where NIR and RED are the reflectances in the near infra-red $(800 \mathrm{~nm})$ and red $(670 \mathrm{~nm})$ bands, respectively. Maps were subsequently processed with a customized Matlab code (The Mathworks Inc., Natick, MA, USA) in order to estimate the intra-orchard spatial variability of NDVI.

The thermal infrared camera (EasIR-9, Wuhan Guide Infrared Co., Wuhan, China) has a resolution of $288 \times 384$ pixels and spectral response in the range 8-14 $\mu \mathrm{m}$ of the electromagnetic spectrum. The built-in sensor is a thermal detector (microbolometer) that avoids the requirement of an external cooling system. Thermal images were post-processed using the proprietary software IRAnalyser (Wuhan Guide Infrared Co., Ltd., Wuhan, China) with consideration given to specific parameters of emissivity, distance to the object, and measurements of $\mathrm{T}_{\mathrm{a}}$ and $\mathrm{RH}$ at 5.5 above the soil surface (Figure 1c).

In each flight campaign, multispectral and thermal images were simultaneously taken at 20 points in the study area (Figure 1b). UAV images were acquired at nearly 0 nadir angle using a gimbal system. Only the central parts of the imagery were used to avoid border effects on the image-derived temperature [41]. The mosaicking of the images was performed using GPS ground control points which consisted on black and white panels that were easily identified from the images [42]. A Matlab 
code was developed to automatically identify the control points based on their respective reflectances. The fractional cover $\left(f_{r}\right)$ was estimated assuming that the tree canopy presented values of NDVI $>0.40$. The separation between the canopy and soil surface was performed manually by using discrimination and segmentation supervised techniques.

\subsection{RSEB Algorithm Adapted for a Helicopter-Based UAV}

A two-source algorithm was implemented to estimate the energy balance (EB) components above the drip-irrigated olive orchard using the thermal and multispectral data acquired by the miniaturized cameras onboard a helicopter-based UAV as input. The partitioning of instantaneous net radiation, which represented a mixture of canopy and soil was estimated as follows [43-46]:

$$
\text { Rne }=\mathrm{f}_{\mathrm{r}} \times \mathrm{Rn}_{\mathrm{c}}+\left(1-\mathrm{f}_{\mathrm{r}}\right) \times \mathrm{Rn}_{\mathrm{s}}
$$

where $R n e$ is the estimated net radiation over the olive orchard; $R n_{C}$ and $R n_{s}$ are the contributions of the canopy and soil, respectively, to Rne; $f_{r}$ is the fractional cover at nadir view. $R n e, R n_{c}$ and $R n_{s}$ are in $\mathrm{W} \mathrm{m}^{-2}$.

Instantaneous values for $R n_{c}$ and $R n_{s}$ were computed by establishing a balance between the long-wave and short-wave radiation, separately, for the soil surface and orchard canopy [16,43]:

$$
\begin{aligned}
& \mathrm{Rn}_{\mathrm{c}}=\left(1-\alpha_{\mathrm{c}}\right) \text { Rse }+ \text { Lin }- \text { Lout }_{\mathrm{c}}-\left(1-\varepsilon_{\mathrm{c}}\right) \text { Lin } \\
& \mathrm{Rn}_{\mathrm{s}}=\left(1-\alpha_{\mathrm{s}}\right) \text { Rse }+ \text { Lin }- \text { Lout }_{\mathrm{s}}-\left(1-\varepsilon_{\mathrm{s}}\right) \text { Lin }
\end{aligned}
$$

where Rse is the instantaneous incoming shortwave radiation; $\alpha_{s}$ and $\alpha_{c}$ are soil and canopy albedos, respectively; Lin is the instantaneous incoming longwave radiation; Lout and Lout $_{\mathrm{s}}$ are the instantaneous outgoing longwave radiations from the soil and canopy, respectively; and $\varepsilon_{\mathrm{C}}$ and $\varepsilon_{\mathrm{S}}$ are the surface thermal emissivities (dimensionless) from the soil and canopy, respectively. In this study, instantaneous values of Rse were estimated according to [16]. Rse, Lin, Lout ${ }_{c}$ and Lout are in $\mathrm{W} \mathrm{m}^{-2}$.

Values of Lin, Lout and Louts at the time of UAV overpass were computed as [16,43]:

$$
\begin{gathered}
\text { Lin }=\varepsilon_{\text {atm }} \sigma \mathrm{T}_{\mathrm{a}}{ }^{4} \\
\varepsilon_{\text {atm }}=0.85\left(-\ln \left(\tau_{s w}\right)\right)^{0.09} \\
\text { Lout }_{\mathrm{c}}=\varepsilon_{\mathrm{c}} \sigma \mathrm{T}_{\mathrm{C}}{ }^{4} \\
\text { Lout }_{\mathrm{s}}=\varepsilon_{\mathrm{S}} \sigma \mathrm{T}_{\mathrm{s}}{ }^{4}
\end{gathered}
$$

where $\sigma$ is the Stefan-Boltzmann constant $\left(\mathrm{W} \mathrm{m} \mathrm{m}^{-2} \mathrm{~K}^{-4}\right) ; \mathrm{T}_{\mathrm{a}}, \mathrm{T}_{\mathrm{c}}$ and $\mathrm{T}_{\mathrm{s}}$ are the air, canopy and soil temperatures between rows, respectively; $\tau_{\mathrm{sw}}$ is the atmospheric transmissivity (dimensionless); and $\varepsilon_{\mathrm{atm}}$ is the atmospheric emissivity (dimensionless). Values of $\varepsilon_{\mathrm{c}}$ and $\varepsilon_{\mathrm{s}}$ were assumed as 0.98 and 0.95 , respectively $[29,47]$. Values of $\mathrm{T}_{\mathrm{a}}, \mathrm{T}_{\mathrm{c}}$ and $\mathrm{T}_{\mathrm{s}}$ are in ${ }^{\circ} \mathrm{K}$. Equation (9) follows the methodology indicated by [16]

The soil and canopy contributions to total sensible heat were estimated using the following equations $[44,45]$ :

$$
\begin{gathered}
\mathrm{He}=\mathrm{f}_{\mathrm{r}} \times \mathrm{H}_{\mathrm{c}}+\left(1-\mathrm{f}_{\mathrm{r}}\right) \times \mathrm{H}_{\mathrm{s}} \\
\mathrm{H}_{\mathrm{c}}=\frac{\rho_{\mathrm{a}} \mathrm{C}_{\mathrm{p}}\left(\mathrm{T}_{\mathrm{c}}-\mathrm{T}_{\mathrm{a}}\right)}{\mathrm{r}_{\mathrm{a}}^{\mathrm{c}}+\mathrm{r}_{\mathrm{a}}^{\mathrm{a}}} \\
\mathrm{H}_{\mathrm{s}}=\frac{\rho_{\mathrm{a}} \mathrm{C}_{\mathrm{p}}\left(\mathrm{T}_{\mathrm{s}}-\mathrm{T}_{\mathrm{a}}\right)}{\mathrm{r}_{\mathrm{a}}^{\mathrm{s}}+\mathrm{r}_{\mathrm{a}}^{\mathrm{a}}}
\end{gathered}
$$

where $\mathrm{He}, \mathrm{H}_{\mathrm{c}}$ and $\mathrm{H}_{\mathrm{s}}$ are the sensible heat fluxes $\left(\mathrm{W} \mathrm{m} \mathrm{m}^{-2}\right)$ above the orchard, tree canopy and soil surface, respectively; $\rho_{a}$ is the air density $\left(\mathrm{kg} \mathrm{m}^{-3}\right) ; \mathrm{C}_{\mathrm{p}}$ is the specific heat of dry air 
$\left(\approx 1005 \mathrm{~J} \mathrm{~kg}^{-1}{ }^{\circ} \mathrm{K}^{-1}\right) ; \mathrm{ra}_{\mathrm{a}}^{\mathrm{c}}$ is the bulk boundary layer resistance of the vegetative elements in the canopy $\left(\mathrm{s} \mathrm{m}^{-1}\right) ; \mathrm{r}_{\mathrm{a}}^{\mathrm{a}}$ is the aerodynamic resistance between canopy source height and reference level $\left(\mathrm{s} \mathrm{m}^{-1}\right)$; and $\mathrm{r}_{\mathrm{a}}^{\mathrm{s}}$ is the aerodynamic resistance between the soil and canopy source height $\left(\mathrm{s} \mathrm{m}^{-1}\right)$. The estimation of $r_{a}^{c}, r_{a}^{a}$ and $r_{a}^{s}$ are estimated according to [35,48] (see Appendix A).

Finally, instantaneous values of latent heat flux over the olive orchard were computed as follows:

$$
\mathrm{LEe}=\mathrm{Rne}-\mathrm{He}-\mathrm{Ge}
$$

In this case, estimated heat flux $\left(\mathrm{Ge}, \mathrm{W} \mathrm{m}^{-2}\right)$ was estimated as:

$$
\mathrm{Ge}=0.3236 \times \text { Rne }-51.52
$$

Equation (16) was developed using a database collected for an olive orchard during the 2009-2010 and 2010-2011 growing seasons [1,49]. The measured values of $\alpha_{\mathrm{s}}, \alpha_{\mathrm{c}}$, and LAI ranged between $0.15-16,0.11-0.12$ and $1.15-1.29 \mathrm{~m}^{2} \mathrm{~m}^{-2}$ while estimated values of $\mathrm{f}_{\mathrm{r}}$ using the UAV ranged between 0.25 and 0.28 .

\subsection{Statistical Analysis}

An analysis of spatial variability of surface temperature $\left(T_{\text {surface }}=T_{s}+T_{c}\right)$, NDVI and energy balance components was made above the tree canopy and above the soil surface between rows. Due to the high resolution of the thermal and multispectral images, crown edges were excluded to ensure that only pure vegetation and soil pixels were used in the comparison between estimated and observed fluxes [50]. In this case, Rne, Ge, He, and LEe were computed by averaging values of $405 \times 405$ $(6 \mathrm{~cm} \times 6 \mathrm{~cm})$ pixels that fell within the footprint of the EC.

The validation of sub-models that compute Rne, Ge, He and LEe was carried out using the ratio of estimated to observed values (b), mean absolute error (MAE), root-mean-square error (RMSE) and index of agreement (Ia) [51,52]. The student's $t$-test analysis was applied to check whether $\mathrm{b}$ was significantly different from unity at the $95 \%$ confidence level. In addition, the sub-model for estimating incoming solar radiation (Rse) was included in the validation. For the validation, measurements of Rsi, $\mathrm{Rn}, \mathrm{G}, \mathrm{HB}$ and LEB between 12:00 and 13:00 were linearly interpolated to compare with the estimated values (Rse, Rne, Ge, He and LEe) at the time of UAV overpass (Table 1).

\section{Results}

Meteorological data obtained at the time of UAV overpasses are indicated in Table 1. Dry and hot atmospheric conditions were observed during the campaigns where values of $\mathrm{Rsi}, \mathrm{T}_{\mathrm{a}}, \mathrm{RH}, \mathrm{u}$ and vapor pressure deficit (VPD) ranged between $801-901 \mathrm{~W} \mathrm{~m}^{-2}, 18.1-24.7^{\circ} \mathrm{C}, 28.4 \%-54.2 \%, 1.0-2.7 \mathrm{~m} \mathrm{~s}^{-1}$, and $0.80-1.4 \mathrm{kPa}$, respectively. Within these atmospheric environments, values of $\Psi_{\mathrm{x}}$ ranged between -1.5 and $-2.1 \mathrm{MPa}$ indicating that the drip-irrigated olive orchard was maintained under non and moderate water stress conditions during the study period [8,53].

The accuracy of the EC measurements above the olive orchard was checked at $15 \mathrm{~min}$ time intervals using energy balance closure which presented a coefficient of determination of 0.92 and $\mathrm{Cr}$ of 0.86 (Figure 2). Table 2 shows that the energy balance closure at the time of UAV overpass was $0.86( \pm 0.03)$ indicating that the orchard energy balance was systematically imbalanced by about $14 \%$. Several researchers have indicated that turbulent fluxes using the EC technique were less than available energy for olive orchard with EC imbalances between $5 \%$ and $26 \%$ [31,36,37,54-57]. Lack of closure may be associated to errors in the measurements of Rn and G [58-60], energy storage within the olive tree biomass [61], low wind speed [62] and heterogeneity of surface energy balance of the region [63]. Finally, [53,64] suggested that EC uncertainties can be corrected using the Bowen-ratio approach $(\beta=\mathrm{H} / \mathrm{LE})$. 


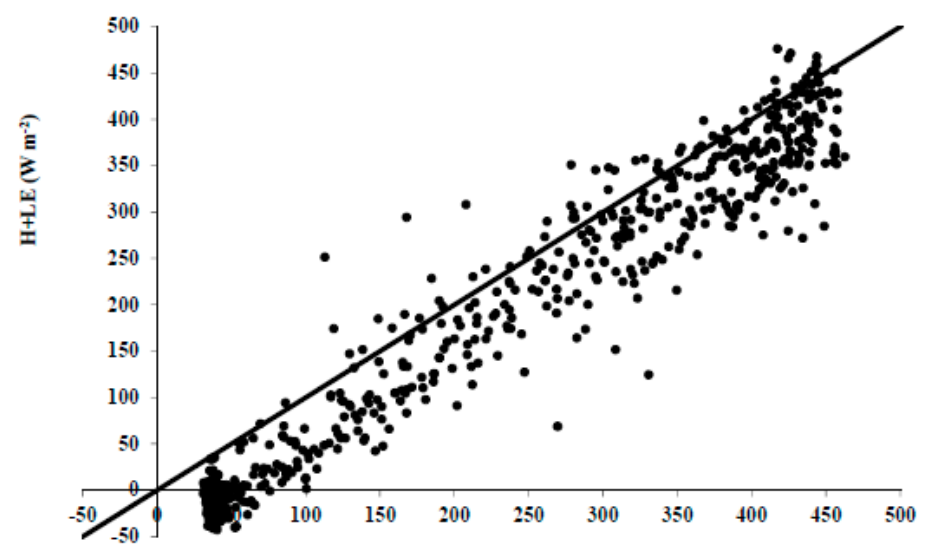

Rn-G (W m-2)

Figure 2. A regression analysis between turbulent energy fluxes $(H+L E)$ from the eddy correlation system and available energy $(\mathrm{Rn}-\mathrm{G})$ over a drip-irrigated olive orchard. The solid line represents the 1:1 line.

Table 2. Energy balance closure $(\mathrm{Cr})$, Bowen ratio $(\beta)$ and instantaneous ratios of latent (LEB), sensible $(\mathrm{HB})$ and soil $(\mathrm{G})$ heat fluxes to net radiation $(\mathrm{Rn})$ over a drip-irrigated olive orchard at the time of UAV overpasses. Instantaneous ratios of Rn to incoming solar radiation (Rsi) are included.

\begin{tabular}{ccccccc}
\hline DOY & $\mathbf{C}_{\mathbf{r}}$ & $\boldsymbol{\beta}$ & $\mathbf{R n} / \mathbf{R s i}$ & $\mathbf{L E B} / \mathbf{R n}$ & HB/Rn & G/Rn \\
\hline 58 & 0.88 & 3.08 & 0.67 & 0.18 & 0.56 & 0.25 \\
59 & 0.87 & 3.87 & 0.67 & 0.15 & 0.59 & 0.25 \\
62 & 0.90 & 3.57 & 0.67 & 0.16 & 0.59 & 0.25 \\
64 & 0.81 & 2.61 & 0.65 & 0.21 & 0.55 & 0.24 \\
65 & 0.86 & 2.61 & 0.67 & 0.21 & 0.54 & 0.25 \\
66 & 0.85 & 2.62 & 0.67 & 0.21 & 0.54 & 0.25 \\
69 & 0.87 & 4.11 & 0.66 & 0.15 & 0.60 & 0.25 \\
73 & 0.81 & 2.77 & 0.66 & 0.20 & 0.55 & 0.25 \\
74 & 0.86 & 2.88 & 0.66 & 0.19 & 0.56 & 0.25 \\
80 & 0.88 & 3.30 & 0.67 & 0.18 & 0.58 & 0.24 \\
Average & $0.86( \pm 0.03)$ & $3.09( \pm 1.7)$ & $0.66( \pm 0.01)$ & $0.18( \pm 0.02)$ & $0.57( \pm 0.02)$ & $0.25( \pm 0.00)$ \\
\hline
\end{tabular}

At the time of UAV overpass (near solar noon), Table 2 indicates that total bulk $\beta$ above the soil-canopy system varied between 2.61 and 4.11 with maximum values observed on DOY 69 . Mean values of LE accounted for $15 \%-21 \%$ of Rn while those of $\mathrm{H}$ were between $54 \%$ and $60 \%$ of $\mathrm{Rn}$. The analysis indicated that the main component of the surface energy balance over the drip-irrigated olive orchard was $\mathrm{H}$. Rn/Rsi and G/Rn ratios were very stable during the study period with mean values of 0.66 and 0.25 , respectively. Results are similar to those found by López-Olivari et al. [1] who indicated that daytime values of $\mathrm{LE}, \mathrm{H}$ and $\mathrm{G}$ over a drip-irrigated olive orchard $\left(\mathrm{f}_{\mathrm{r}}=30 \%\right)$ were between $28 \%-47 \%, 34 \%-68 \%$ and $2 \%-6 \%$ of Rn, respectively, while ratios of transpiration and soil evaporation to ETa ranged between $0.64-0.74$ and $0.26-0.36$, respectively.

The intra-orchard spatial variability of NDVI and surface temperature is indicated in Figure 3 based on multispectral and thermal imagery collected by the helicopter-based UAV. This Figure confirms the degree that $\mathrm{NDVI}_{\mathrm{C}}$ (canopy) was larger than $\mathrm{NDVI}_{\mathrm{S}}$ (soil surface) and that $\mathrm{T}_{\mathrm{c}}$ was less than $T_{s}$ during the study period. Figure 4 indicates that averaged values of $\mathrm{NDVI}_{\mathrm{C}}$ and $\mathrm{NDVI}_{\mathrm{S}}$ during the data collection period ranged between $0.63-0.71$ and $0.11-0.16$, respectively while Figure 5 shows that $\mathrm{T}_{\mathrm{C}}$ and $\mathrm{T}_{\mathrm{s}}$ were between $16.1-27.7$ and $39.9-51.9^{\circ} \mathrm{C}$, respectively. The coefficients of variation $(\mathrm{CV})$ of $\mathrm{NDVI}_{\mathrm{c}}, \mathrm{NDVI}_{\mathrm{s}}, \mathrm{T}_{\mathrm{c}}$ and $\mathrm{T}_{\mathrm{s}}$ were $5.1 \%, 6.2 \%, 8.0 \%$ and $9.3 \%$, respectively. These results indicate that spatial variability of $\mathrm{T}_{\mathrm{C}}$ and $\mathrm{T}_{\mathrm{S}}$ was greater than that of $\mathrm{NDVI}_{\mathrm{C}}$ and $\mathrm{NDVI}_{\mathrm{S}}$ during the flight campaigns. 
Furthermore, $\mathrm{NDVI}_{\mathrm{c}}, \mathrm{NDVI}_{\mathrm{S}}, \mathrm{T}_{\mathrm{c}}$ and $\mathrm{T}_{\mathrm{s}}$ presented a low spatial variability because $\mathrm{CV}$ values were less than $15 \%$ [65].
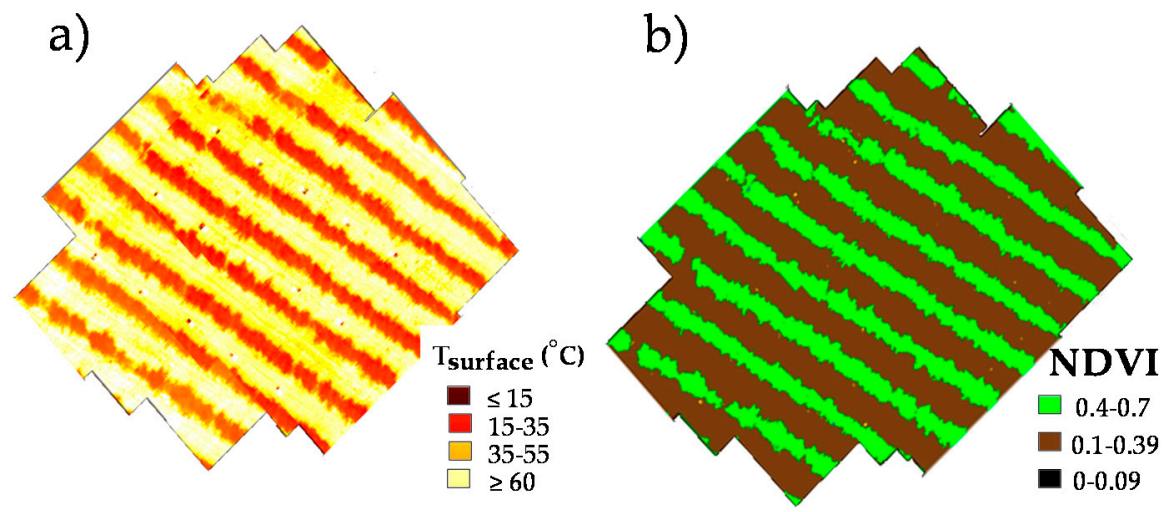

Figure 3. $(\mathbf{a}, \mathbf{b})$ Averaged spatial distribution of the normalized difference vegetation index (NDVI) and surface temperature (Tsurface) over a drip-irrigated olive orchard using multispectral and thermal cameras, respectively, placed aboard an unmanned aerial vehicle (UAV).

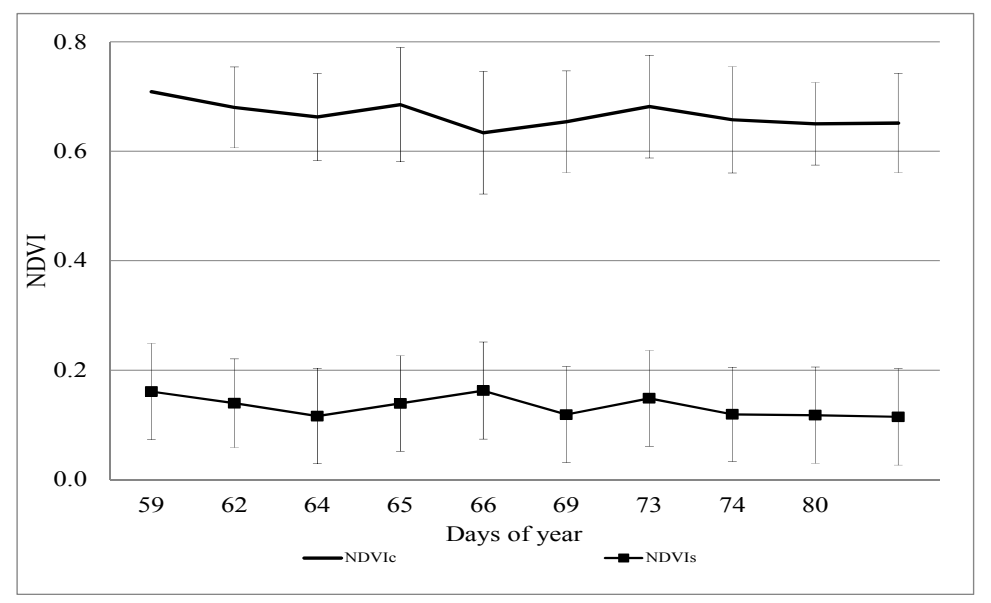

Figure 4. Mean values of the normalized difference vegetation index of (NDVI) of a drip-irrigated olive orchard using a multispectral camera placed aboard an unmanned aerial vehicle (UAV). Sub-indexes " $c$ " and "s" denote values from the canopy and soil surface, respectively. Vertical lines indicate one standard deviation.

Figure 6 shows comparisons between observed and estimated values of solar radiation and energy balance components at the time of UAV overpass (near solar noon). For solar radiation (black squares) and net radiation (black circles), all points were close to the 1:1 line. Values of RMSE and MAE for solar radiation were 24 and $21 \mathrm{~W} \mathrm{~m}^{-2}$, respectively, while those for net radiation were 38 and $33 \mathrm{~W} \mathrm{~m}^{-2}$ (Table 3). The $t$-test indicated that the Rse/Rso ratio was not significantly different from unity, indicating that observed and estimated values were similar. However, the Rne/Rno ratio was statistically less than unity, where net radiation was underestimated by about $5.0 \%$. These results are similar to those indicated in the literature for sparse canopies when using satellite-based remote sensing (SBRS) models. For a heterogeneous landscape in China, Liu et al. [66] showed values of RMSE and MAE equal to 51 and $25 \mathrm{~W} \mathrm{~m}^{-2}$, respectively, when using a simplified SBRS model. For a drip-irrigated vineyard, Carrasco-Benavides et al. [14] indicated that the METRIC model overestimated instantaneous Rn by about $11 \%$ with RMSE $=69.4 \mathrm{~W} \mathrm{~m}^{-2}$ and MAE $=63 \mathrm{~W} \mathrm{~m}^{-2}$. For a drip-irrigated olive orchard, Ortega-Farias et al. [67] indicated that the METRIC model underestimated the instantaneous values of Rn by about $3 \%$ with RMSE and MAE values of 40 and $33 \mathrm{~W} \mathrm{~m}^{-2}$, respectively. 


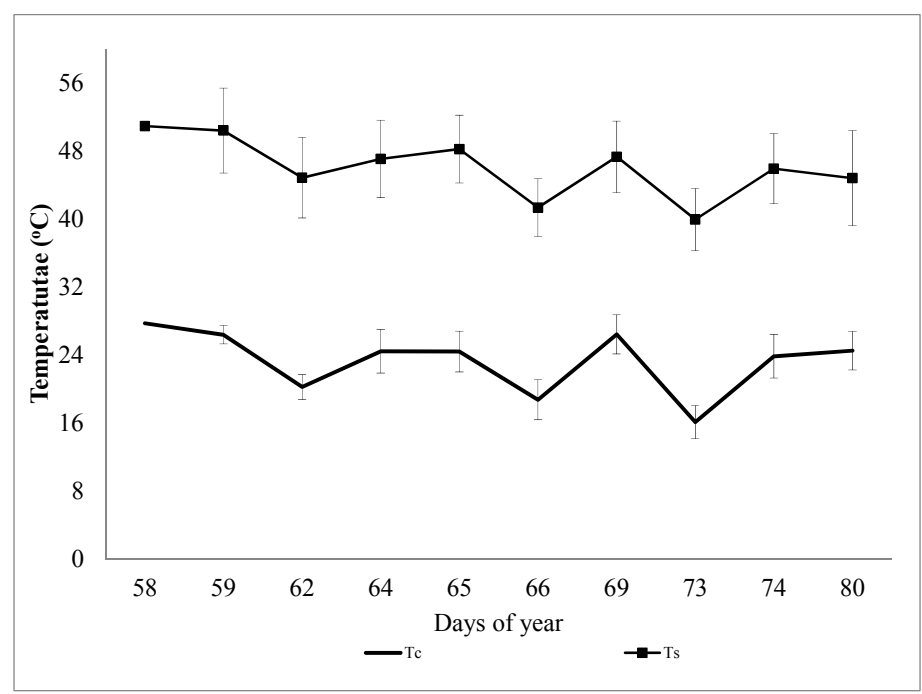

Figure 5. Mean values of surface temperature over a drip-irrigated olive orchard using a thermal camera placed aboard an unmanned aerial vehicle (UAV). Sub-indexes " $c$ " and " $s$ " denote values from the canopy and soil surface, respectively. Vertical lines indicate one standard deviation.

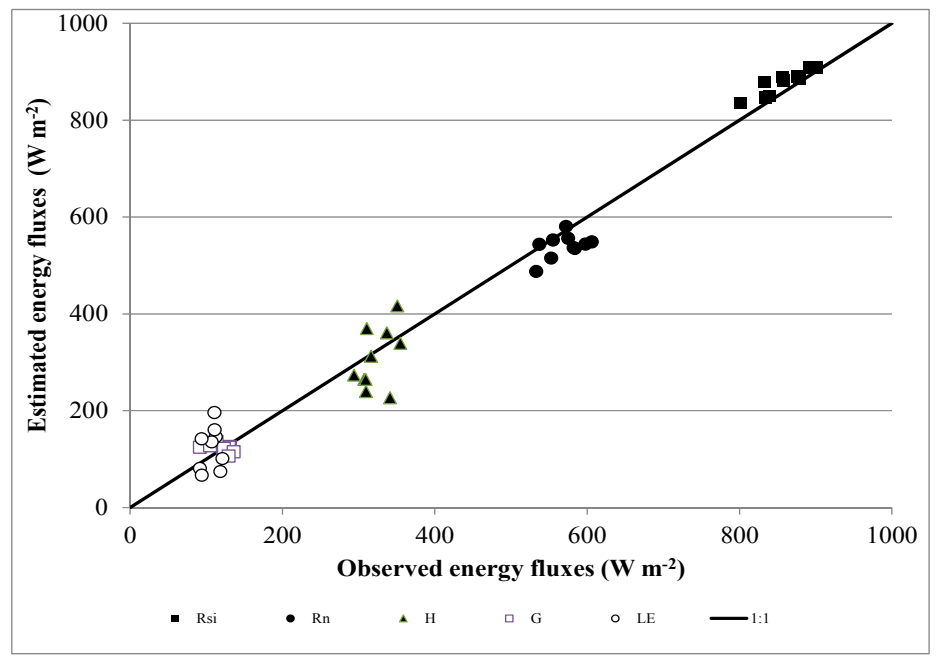

Figure 6. Comparisons at the time of UAV overpass between observed (axis X) and estimated (axis $\mathrm{Y}$ ) values of bulk (canopy and soil) incoming solar radiation (Rsi) net radiation (Rn), soil heat flux (G), sensible heat flux $(\mathrm{H})$, and latent heat flux (LE) over a drip irrigated olive orchard.

Table 3. Validation of sub-models that compute solar radiation (Rsi), net radiation (Rn), sensible heat flux $(\mathrm{H})$, soil heat flux $(\mathrm{G})$ and latent heat flux (LE) over a drip-irrigated olive orchard at the time of UAV overpass.

\begin{tabular}{|c|c|c|c|c|c|}
\hline Variable & RMSE $\left(\mathrm{W} \mathrm{m}^{-2}\right)$ & MAE $\left(\mathrm{W} \mathrm{m}^{-2}\right)$ & b & Ia & $t$-Test \\
\hline Rsi & 24 & 21 & 1.02 & 0.92 & $\mathrm{~T}$ \\
\hline $\mathrm{Rn}$ & 38 & 33 & 0.95 & 0.88 & $\mathrm{~F}$ \\
\hline G & 19 & 16 & 1.02 & 0.66 & $\mathrm{~T}$ \\
\hline $\mathrm{HB}$ & 56 & 46 & 0.95 & 0.74 & F \\
\hline LEB & 50 & 43 & 1.07 & 0.54 & $\mathrm{~F}$ \\
\hline
\end{tabular}

RMSE = root mean square error; MAE = mean absolute error; $b$ = ratio of observed to computed values; Ia $=$ index of agreement; $\mathrm{T}=$ null hypothesis $(\mathrm{b}=1)$ True; $\mathrm{F}=$ alternative hypothesis $(\mathrm{b} \neq 1)$. 
Comparisons between measured and estimated sensible heat fluxes at the time of UAV overpasses (Figure 6-black triangles) show that the points were evenly distributed along the 1:1 line. In this case, the sub-model underestimated the instantaneous sensible heat fluxes by about 5\% with RMSE and MAE equal to 56 and $46 \mathrm{~W} \mathrm{~m}^{-2}$, respectively (Table 3). The best agreement between measured and estimated sensible heat fluxes was observed on DOY 65 (5 March) where the differences between HB and He were less than $20 \mathrm{~W} \mathrm{~m}^{-2}$. The greatest disagreement was observed on DOY 69 where HB and He were 351 and $416 \mathrm{~W} \mathrm{~m}^{-2}$, respectively. In general, largest differences were observed when wind speed was $>2.7 \mathrm{~m} \mathrm{~s}^{-1}$. Over heterogeneous surfaces, Chávez et al. [64] indicated that the RMSE was $23 \mathrm{~W} \mathrm{~m}^{-2}$ when a simplified SBRS model was applied to estimate the sensible heat flux at the time of satellite overpass. For a drip-irrigated vineyard, Carrasco-Benavides et al. [14] found that METRIC with the calibrated functions of LAI, roughness length $\left(\mathrm{z}_{\mathrm{OM}}\right)$ and $\mathrm{G}$ overestimated instantaneous values of $\mathrm{H}$ by about $16 \%$ with RMSE and MAE equal to 67 and $57 \mathrm{~W} \mathrm{~m}^{-2}$, respectively.

The comparison between measured and modeled soil heat fluxes (open squares) in Figure 6 shows that there was an equilibrated distribution of points around the 1:1 line. In this case, instantaneous values of $\mathrm{G}$ were estimated with an error $=2 \%, \mathrm{RMSE}=19 \mathrm{~W} \mathrm{~m}^{-2}$ and MAE $=16 \mathrm{~W} \mathrm{~m}^{-2}$ (Table 3). Over heterogeneous surfaces, Shaomin et al. [68], using a remote sensing model, estimated soil heat fluxes with an error $=19 \%$ and $\mathrm{RMSE}=23 \mathrm{~W} \mathrm{~m}^{-2}$ and suggested that errors could be attributed to differences in spatial/temporal scales between satellite data and ground-truth measurements. Similarly, Carrasco-Benavides et al. [14] observed for a drip-irrigated vineyard that METRIC simulated G with an error, RMSE and MAE of $17 \%, 34 \mathrm{~W} \mathrm{~m}^{-2}$ and $21 \mathrm{~W} \mathrm{~m}^{-2}$, respectively.

For the instantaneous latent heat flux, Figure 6 (open circles) shows that the points were grouped above the 1:1 line with a RMSE $=50 \mathrm{~W} \mathrm{~m}^{-2}$ and MAE $=43 \mathrm{~W} \mathrm{~m}^{-2}$ (Table 3). The LEe/LEo ratio was significantly different from unity suggesting that the RSEB algorithm overestimated instantaneous values of LE by about 7\%. For drip-irrigated vineyards, González-Dugo et al. [69] observed errors of $18 \%$ in the estimation of LE when using a two-source energy balance (TSEB) model and Landsat scenes. For a drip-irrigated Merlot vineyard, Carrasco-Benavides et al. [14] indicated that METRIC using calibrated functions, overestimated LE with error $=17 \%, \mathrm{RMSE}=60 \mathrm{~W} \mathrm{~m}^{-2}$ and $\mathrm{MAE}=48 \mathrm{~W} \mathrm{~m}^{-2}$. For a drip-irrigated olive orchard, Ortega-Farias et al. [70] observed that the METRIC model underestimated LE by about $11 \%$ with RMSE $=29 \mathrm{~W} \mathrm{~m}^{-2}$ and MAE $=26 \mathrm{~W} \mathrm{~m}^{-2}$.

For high-resolution multispectral and thermal imagery obtained by aircraft mounted sensors, Xia et al. [71] observed that a two-source energy balance (TSEB) was able to simulate the energy balance components over two vineyards with MAE values ranging between 15 and $90 \mathrm{~W} \mathrm{~m}^{-2}$. These authors concluded that the TSEB model is fairly robust and able to derive reliable LE and ET patterns at sub-field scale under a wide range of environmental conditions. For a lightweight thermal camera mounted on a UAV, Homann et al. [72] indicated that the TSEB estimated the energy balance components over a barley field with RMSE and MAE ranging between 38-94 and 33-84 $\mathrm{W} \mathrm{m}^{-2}$, respectively. They suggested that the lightweight thermal camera placed on UAV platform provided high spatial and temporal resolution data for estimating energy balance fluxes over a barley field.

At the time of the UAV overpass, Figure 7 shows maps with the intra-orchard spatial variability of the energy balance components estimated by the RSEB algorithm. The Figure also shows that the maps at very high spatial resolution (pixels $=6 \mathrm{~cm} \times 6 \mathrm{~cm}$ ) are detailed enough to show differences between the energy balance components above the tree canopy and the soil surface between rows. Figure $7 a$ indicates that $R n_{c}$ was greater than $R n_{s}$ with $C V$ values of $5.5 \%$ and $6.1 \%$, respectively. The average values of $\mathrm{H}_{\mathrm{c}}$ and $\mathrm{H}_{\mathrm{s}}$ were 46 and $397 \mathrm{~W} \mathrm{~m}{ }^{-2}$ while those of $\mathrm{LE}_{\mathrm{c}}$ and $\mathrm{LE}_{\mathrm{s}}$ were 573 and $30 \mathrm{~W} \mathrm{~m}^{-2}$, respectively. In addition, the values of $\mathrm{CV}$ ranged between $6 \%$ and $13 \%$ for $\mathrm{H}_{\mathrm{C}}, \mathrm{H}_{\mathrm{s}}, \mathrm{LE}_{\mathrm{C}}$ and $\mathrm{LE}_{\mathrm{s}}$ suggesting that the spatial variability of turbulent fluxes was low for the olive orchard [65]. 

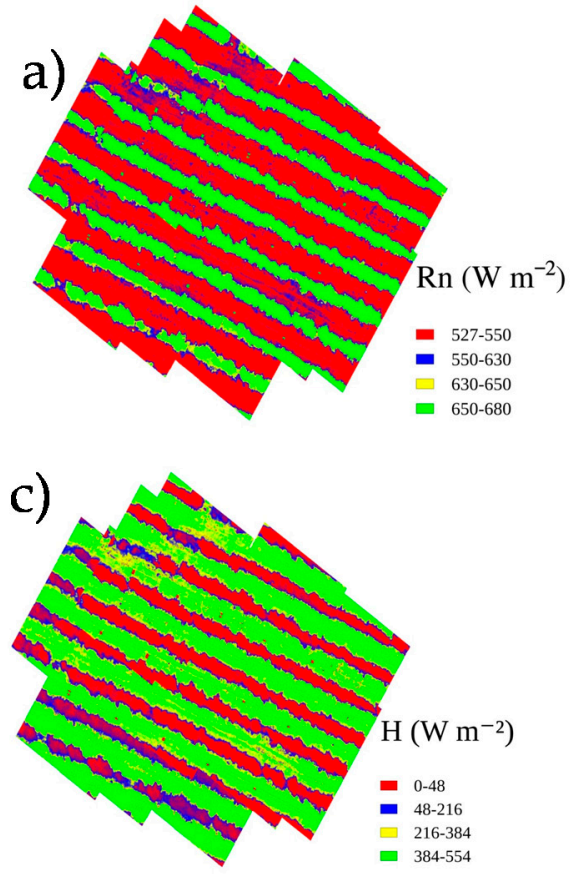

b)

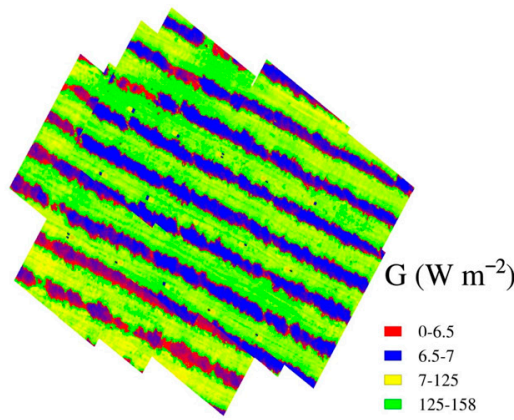

d)

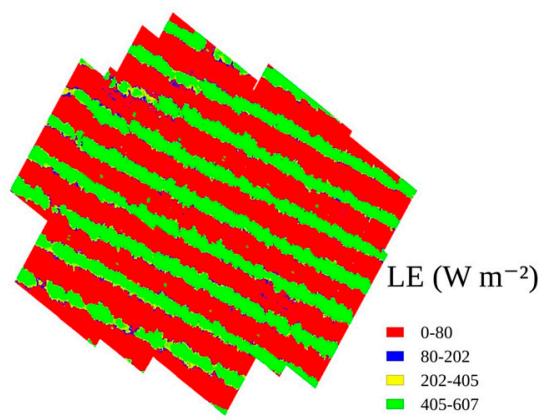

Figure 7. Average spatial distribution of estimated values of (a) net radiation (Rn); (b) soil heat flux $(\mathrm{G})$; (c) sensible heat flux $(\mathrm{H})$; and (d) latent heat flux (LE) over the olive canopy and soil surface between rows using a thermal sensor placed aboard an unmanned aerial vehicle (UAV).

\section{Discussions}

The results (RMSE, MAE and errors) obtained in this research coincide with those reported in the literature for sparse vineyards and orchards using satellite, aircraft and UAV platforms $[14,64,66-69,71,72]$. The implementation of the RSEB algorithm was well defined and the only input data used to simulate orchard energy balance were measurements of climatic variables $\left(\mathrm{Ta}, \mathrm{u}\right.$, and RHa) and UAV images (NDVI and $\mathrm{T}_{\text {surface }}$ ). The results also indicated that the maps at very high spatial resolution were able to show significant differences between the energy balance fluxes above the tree canopy and the soil surface between rows. Moreover, the values of $\mathrm{Rn}_{\mathrm{c}}$ and $\mathrm{LE}_{\mathrm{c}}$ were greater than those of $\mathrm{Rn}_{\mathrm{s}}$ and $L E_{s}$ while those of $T_{c}$ and $\mathrm{H}_{\mathrm{c}}$ were significantly less than those of $T_{S}$ and $\mathrm{H}_{\mathrm{s}}$ (Figure 7). This study demonstrated that multispectral and thermal cameras placed on an UAV could provide an excellent tool to evaluate the effects of spatial variability on the partitioning of $\mathrm{Rn}$ into G, H and LE over heterogeneous orchards. Finally, UAV could be a useful complement to current satellite platforms for estimating intra-field spatial variability of the energy balance components in order to improve the estimation of water requirements of sparse or complex canopies such as orchards and vineyards which, in turn, present different plant densities and fractional covers.

The water requirements of drip-irrigated olive orchards require a good knowledge of $\mathrm{H} / \mathrm{Rn}$, $\mathrm{G} / \mathrm{Rn}$ and LE/Rn ratios, which depends on tree vigor. The vigor is manifested through the canopy size, LAI, and $\mathrm{f}_{\mathrm{r}}$. In this regard, López-Olivari et al. [1] suggested that the canopy architecture (tree density, canopy size, LAI, and $\mathrm{f}_{\mathrm{r}}$ ), pruning, and irrigation systems (percentage of wetted area of soil surface) have an important effect on the partitioning of Rn into LE, H and G. Similarly, Testi et al. [62] suggested that the energy exchange between the soil surface and the tree canopy is strongly affected by the orchard architecture and fractional cover. According to the canopy structure and fractional cover, $\mathrm{H}$ generated at the soil surface can be a major contributor to the orchard energy balance, which plays a key role in the tree transpiration and evaporation. During this study, the canopy cover was generally incomplete as a result of the regimented structure imposed by the triangular hedgerow system. This training system consisted of widely spaced trees that allowed for deep penetration of 
sunlight and air turbulence into the canopy. For the drip-irrigated olive orchard, a constant shape of the canopy was maintained with values of LAI and $\mathrm{f}_{\mathrm{r}}$ ranging between $1.15-1.29 \mathrm{~m}^{2} \mathrm{~m}^{-2}$ and $0.25-0.28 \mathrm{~m}^{2} \mathrm{~m}^{-2}$, respectively. The soil surface between rows was kept free of weeds (cover crops) during February and March; during this time rainfall was less than $5 \mathrm{~mm}$. In addition, the soil surface $(0-20 \mathrm{~cm})$ between rows was very dry and the soil surface wetted by drip emitters was $4.5 \%$. In these orchard conditions, values of $\alpha_{s}, \alpha_{c}, \mathrm{NDVI}_{\mathrm{c}}$ and $\mathrm{NDVI}_{\mathrm{s}}$ were quite constant during the study period, making it possible to carry out a good comparison between the observed and the estimated values of the net radiation and soil heat flux at the time of the UAV overpass. In addition, sensible heat flux generated at the soil surface between rows was the main component of the orchard energy balance which affected the partitioning of LE into $\mathrm{LE}_{\mathrm{c}}$ (transpiration) and $\mathrm{LE}_{\mathrm{S}}$ (soil evaporation). In this case, the $\mathrm{H}_{\mathrm{c}} / \mathrm{H}_{\mathrm{s}}$ and $\mathrm{LE}_{\mathrm{c}} / \mathrm{LE}_{\mathrm{s}}$ ratios were 0.21 and 7.64, respectively, for the olive orchard that was also maintained under non and moderate water stress conditions. Finally, $\mathrm{NDVI}_{\mathrm{C}}, \mathrm{NDVI}_{\mathrm{S}}, \mathrm{T}_{\mathrm{C}}$ and $\mathrm{T}_{\mathrm{S}}$ presented a low spatial variability $(\mathrm{CV}<15 \%)$ because LAI and $\mathrm{f}_{\mathrm{r}}$ were maintained constant by the triangular hedgerow system.

\section{Conclusions}

This study indicates that the use of both multispectral and thermal cameras onboard of the UAV allowed acquisition of high-resolution images to assess the intra-field spatial variability of energy balance components over a drip-irrigated olive orchard under non and moderate water stress conditions (midday $\Psi x>-2.1 \mathrm{MPa}$ ). Simulated net radiation, soil, sensible, and latent heat fluxes were generally in good agreement with flux measurements from an eddy covariance system located within the olive orchard. In this experiment, RSEB algorithm estimated instantaneous values of Rn, H, G and LE with errors less than 7\%. Disagreement between modeled and measurements were associated with the estimation of sensible heat flux, especially on days where wind speed was greater than $>2.7 \mathrm{~m} \mathrm{~s}^{-1}$.

In addition, this experiment demonstrated that multispectral and thermal cameras placed on an UAV could provide an excellent tool to evaluate the effects of intra-orchard spatial variability of Rn, G, H, LE, NDVI and $T_{\text {surface }}$ over the tree canopy and soil surface between rows. In this cases, the maps at very high spatial resolution (pixels $=6 \mathrm{~cm} \times 6 \mathrm{~cm}$ ) are detailed enough to show differences between the energy balance components above the tree canopy and the soil surface between rows. In addition, sensible heat flux generated at the soil surface between rows was the main component of the orchard energy balance, which affected the partitioning of LE into LEc (transpiration) and LEs (soil evaporation). Finally, the coefficient of variation indicated that intra-canopy and intra-row spacing spatial variability of $\mathrm{T}_{\text {surface }}$ was greater than that of NDVI during the flight campaigns.

Future improvements will incorporate spatially distributed multispectral data into the RSEB models in order to estimate the intra-field spatial variability of albedo, leaf area index, and surface emissivity. In addition, parameterization of aerodynamic resistance approaches will be required to simulate sensible heat flux over heterogeneous orchards, which consist of widely spaced trees that allow for deep penetration of sunlight and air turbulence into the canopy. Finally, future work will evaluate the parameterization of turbulent fluxes and available energy over the tree canopy and soil surface between rows.

Acknowledgments: This study was supported by the Chilean government through the projects FONDECYT (No. 1130729) and FONDEF (No. D10I1157). The authors would like to thank Manuel Barrera and Alvaro Ried from the "Olivares de Quepu" Company for their technical support.

Author Contributions: Samuel Ortega-Farias conceived and designed the experiments, supported the statistical analysis, and wrote the original manuscript draft. Ayse Kilic, Richard Allen and Carlos Poblete-Echeverría contributed extensively to results interpretation and discussions and editing of the manuscript. Luis Ahumada-Orellana and Mauricio Zuñiga supported the field experiment and helped with editorial contributions. Samuel Ortega-Salazar and Tomas Poblete analyzed UAV images and supported the statistical analysis. Daniel Sepúlveda performed the UAV flights and analyzed field data. All co-authors contributed valuable information to the final version.

Conflicts of Interest: The authors declare no conflict of interest. 


\section{Appendix A. Expressions to Estimate the Aerodynamic Resistances in the RSEB Algorithm}

Values of $r_{a}^{a}$ and $r_{a}^{s}$ were estimated by the following expressions [35,48]:

$$
\begin{aligned}
& \mathrm{r}_{\mathrm{a}}^{\mathrm{a}}=\frac{\mathrm{LAI}}{20} \mathrm{r}_{\mathrm{a}}^{\mathrm{a}}(\propto)+\frac{(4-\mathrm{LAI})}{20} \mathrm{r}_{\mathrm{a}}^{\mathrm{a}}(0) \\
& \mathrm{r}_{\mathrm{a}}^{s}=\frac{\mathrm{LAI}}{10} \mathrm{r}_{\mathrm{a}}^{s}(\propto)+\frac{(4-\mathrm{LAI})}{10} \mathrm{r}_{\mathrm{a}}^{s}(0) \\
& \mathrm{r}_{\mathrm{a}}^{\mathrm{s}}(0)=\frac{\ln \left(\frac{\mathrm{x}}{\mathrm{z}_{\mathrm{o}}}\right) \ln \left(\frac{\mathrm{d}+\mathrm{z}_{\mathrm{o}}}{\mathrm{z}_{\mathrm{o}}}\right)}{\mathrm{uk}^{2}} \\
& \mathrm{r}_{\mathrm{a}}^{\mathrm{a}}(0)=\frac{\ln \left(\frac{\mathrm{x}}{\mathrm{z}_{\mathrm{o}}}\right) \ln \left(\frac{\mathrm{x}}{\mathrm{z}_{\mathrm{o}}}\right)}{\mathrm{uk}^{2}}-\mathrm{r}_{\mathrm{a}}^{\mathrm{s}}(0) \\
& \mathrm{r}_{\mathrm{a}}^{\mathrm{s}}(\alpha)=\frac{\ln \left(\frac{\mathrm{x}-\mathrm{d}}{\mathrm{z}_{\mathrm{OM}}}\right)}{\mathrm{uk}^{2}} \frac{\mathrm{h}}{\mathrm{n}(\mathrm{h}-\mathrm{d})}\left[\exp (\mathrm{n})-\exp \left[\mathrm{n}\left\{1-\frac{\mathrm{d}+\mathrm{z}_{\mathrm{OM}}}{\mathrm{h}}\right\}\right]\right] \\
& \mathrm{r}_{\mathrm{a}}^{\mathrm{a}}(\alpha)=\frac{\ln \left(\frac{\mathrm{x}-\mathrm{d}}{\mathrm{z}_{\mathrm{OM}}}\right)}{\mathrm{uk}^{2}}\left\{\ln \left(\frac{\mathrm{x}-\mathrm{d}}{\mathrm{h}-\mathrm{d}}\right)+\frac{\mathrm{h}}{\mathrm{n}(\mathrm{h}-\mathrm{d})}\left[\exp \left[\mathrm{n}\left\{1-\frac{\mathrm{d}+\mathrm{z}_{\mathrm{OM}}}{\mathrm{h}}\right\}\right]-1\right]\right\}
\end{aligned}
$$

where $r_{a}^{a}(\alpha)$ is the value for $r_{a}^{a}$ for a crop with complete canopy cover $(L A I=4)\left(s^{-1}\right)$; $r_{a}^{a}(0)$ is the value of $r_{a}^{a}$ for bare soil $\left(\mathrm{s} \mathrm{m}^{-1}\right) ; r_{a}^{s}(\alpha)$ is the value of $r_{a}^{s}$ for a crop with complete canopy cover $(L A I=4)$ $\left(\mathrm{s} \mathrm{m}^{-1}\right) ; \mathrm{r}_{\mathrm{a}}^{\mathrm{s}}(0)$ is the value for $\mathrm{r}_{\mathrm{a}}^{\mathrm{s}}$ bare soil $\left(\mathrm{s} \mathrm{m}^{-1}\right) ; \mathrm{x}$ is the reference height above the crop where meteorological measurements are available $(\mathrm{m})$; $\mathrm{d}$ is the zero plane displacement of crop with complete canopy cover $(\mathrm{LAI}=4)(\mathrm{m})$; $\mathrm{z}_{\mathrm{OM}}$ is the roughness length of crop with complete canopy cover $(\mathrm{LAI}=4)$ $\left(\mathrm{s} \mathrm{m}^{-1}\right) ; \mathrm{z}_{\mathrm{o}}$ is the roughness length of the bare soil $(\mathrm{m}) ; \mathrm{u}$ is the wind speed at the reference height $\left(\mathrm{m} \mathrm{s}^{-1}\right) ; \mathrm{k}$ is the von Kármán's constant; $\mathrm{h}$ is the canopy height $(3.2 \mathrm{~m})$; and $\mathrm{n}$ is the eddy diffusivity decay constant in a crop with complete canopy cover ( $(\mathrm{AI}=4)$ (dimensionless). Values of $n, x, h, d$, $\mathrm{z}_{\mathrm{OM}}, \mathrm{z}_{\mathrm{o}}^{\prime}$ and $\mathrm{k}$ are indicated in Table A1.

Finally, $r_{a}^{c}$ was calculated as [31]:

$$
\mathrm{r}_{\mathrm{a}}^{\mathrm{c}}=\frac{\mathrm{r}_{\mathrm{b}}}{\mathrm{LAI}} \text { active }
$$

where $r_{b}$ is the mean boundary layer resistance $\left(25 \mathrm{~s} \mathrm{~m}^{-1}\right)$; and $\mathrm{LAI}_{\text {active }}$ is the active (sunlit) leaf area index $\left(=0.5 \mathrm{LAI}, \mathrm{m}^{2} \mathrm{~m}^{-2}\right)$, which corresponds to the upper, well illuminated leaves that most contribute to transpiration.

Table A1. List of constants used in the aerodynamic resistances.

\begin{tabular}{cccc}
\hline Symbol & Name & Value & \\
\hline $\mathrm{n}$ & eddy diffusivity decay coefficient & 2.5 & obtained from [47] \\
$\mathrm{x}$ & reference height & $5.5 \mathrm{~m}$ & Measured \\
$\mathrm{h}$ & height of the canopy & $3.2 \mathrm{~m}$ & Measured \\
$\mathrm{d}$ & displacement height $(0.63 \times \mathrm{h})$ & $2.02 \mathrm{~m}$ & obtained from [47] \\
$\mathrm{z}_{\mathrm{OM}}$ & roughness length of crop $(0.05 \times \mathrm{h})$ & $0.16 \mathrm{~m}$ & obtained from [47] \\
$\mathrm{z}_{\mathrm{o}}^{\prime}$ & roughness length of the bare soil $\left(0.1 \times \mathrm{z}_{\mathrm{O}}\right)$ & $0.016 \mathrm{~m}$ & obtained from [47] \\
$\mathrm{k}$ & Von Karman's constant & 0.41 & obtained from [47] \\
$\mathrm{r}_{\mathrm{b}}$ & mean boundary layer resistance & $25 \mathrm{~s} \mathrm{~m}^{-1}$ & \\
\hline
\end{tabular}

\section{References}

1. López-Olivari, R.; Ortega-Farías, S.; Poblete-Echeverría, C. Partitionning of net radiation and evapotranspiration over a superintensive drip-irrigated olive orchard. Irrig. Sci. 2016, 1, 17-31. [CrossRef] 
2. Intergovernmental Panel on Climate Change (IPCC). The Fifth Assessment Report (AR5); World Meteorological Organization (WMO): Geneva, Switzerland; United Nations Environment Programme (UNEP): Nairobi, Kenya, 2013.

3. Fereres, E.; Soriano, M.A. Deficit irrigation for reducing agricultural water use. J. Exp. Bot. 2007, 58, 147-159. [CrossRef] [PubMed]

4. Ortega-Farias, S.; Irmak, S.; Cuenca, R.H. Special issue on evapotranspiration measurement and modeling. Irrig. Sci. 2009, 28, 1-3. [CrossRef]

5. Allen, R.G.; Pereira, L.S.; Raes, D.; Smith, M. Crop Evapotranspiration. Guidelines for Computing Crop Water Requirements; FAO Irrigation and Drainage Paper No. 56; Food and Agriculture Organization of the United Nations: Rome, Italy, 1998.

6. Ortega-Farías, S.; Cuenca, R.H.; English, M. Hourly grass evapotranspiration in modified maritime environment. J. Irrig. Drain. Syst. 1995, 6, 369-373. [CrossRef]

7. Alegre, S.; Marsal, J.; Mata, M.; Arbones, A.; Girona, J.; Tovar, M. Regulated deficit irrigation in olive trees (Olea europaea L. cv. 'Arberquina') for oil production. Acta Hortic. 2002, 586, 259-262. [CrossRef]

8. Flores, F.; Ortega-Farías, S. Effect of Three Levels of Water Application on Oil Yield and Quality for an Olive ('Picual') Orchard. Acta Hortic. (ISHS) 2011, 889, 317-322. [CrossRef]

9. Patumi, M.; D’Andria, R.; Marsilio, V.; Fontanazza, G.; Morelli, G.; Lanza, B. Olive and olive oil quality after intensive monocone olive growing (Olea europaea L., cv. Kalamata) in different irrigation regimes. Food Chem. 2002, 77, 27-34. [CrossRef]

10. Tognetti, R.; d'Andria, R.; Morelli, G.; Alvino, A. The effect of deficit irrigation on seasonal variations of plant water use in Olea europaea L. Plant Soil 2005, 273, 139. [CrossRef]

11. Cohen, Y.; Alchanatis, V.; Meron, M.; Saranga, S.; Tsipris, J. Estimation of leaf water potential by thermal imagery and spatial analysis. J. Exp. Bot. 2005, 56, 1843-1852. [CrossRef] [PubMed]

12. Ortega-Farias, S.; Rigetti, T.; Acevedo, C.; Matus, F.; Moreno, Y. Irrigation-management decision system (IMDS) for vineyards (Region VI and VII of Chile). Integrated Soil Water Management for Orchard Development. FAO Land Water Bull. 2005, 10, 59-64.

13. Carrasco-Benavides, M.; Ortega-Farías, S.; Lagos, L.O.; Kleissl, J.; Morales, L.; Poblete-Echeverría, C.; Allen, R.G. Crop coefficients and actual evapotranspiration for a drip-irrigated Merlot vineyard using multispectral satellite images. Irrig. Sci. 2012, 30, 537-553. [CrossRef]

14. Carrasco-Benavides, M.; Ortega-Farías, S.; Lagos, L.O.; Kleissl, J.; Morales-Salinas, L.; Kilic, A. Parameterization of the Satellite-Based Model (METRIC) for the estimation of instantaneous surface energy balance components over a drip-irrigated vineyard. Remote Sens. 2014, 6, 11342-11371. [CrossRef]

15. Samani, Z.; Bawazir, A.S.; Bleiweiss, M.; Skaggs, R.; Longworth, J.; Tran, V.D.; Pinon, A. Using remote sensing to evaluate the spatial variability of evapotranspiration and crop coefficient in the lower Rio Grande Valley, New Mexico. Irrig. Sci. 2009, 1, 93-100. [CrossRef]

16. Allen, R.G.; Tasumi, M.; Morse, A.; Trezza, R.; Wright, J.L.; Bastiaanssen, W.; Kramber, W.; Lorite, I.; Robison, C.W. Satellite-based energy balance for mapping evapotranspiration with internalized calibration (METRIC) applications. J. Irrig. Drain. Eng. ASCE 2007, 4, 395-406. [CrossRef]

17. Bastiaanssen, W.G.M.; Menenti, M.; Feddes, R.A.; Holtslag, A.A.M. A remote sensing surface energy balance algorithm for land (SEBAL) -1. Formulation. J. Hydrol. 1998, 1-4, 198-212. [CrossRef]

18. Bastiaanssen, W.G.; Noordman, J.M.; Pelgrum, H.; Davids, G.; Thoreson, B.P.; Allen, R.G. SEBAL model with remotely sensed data to improve water-resources management under actual field conditions. J. Irrig. Drain. Eng. ASCE 2005, 1, 85-93. [CrossRef]

19. Bastiaanssen, W.G.M. SEBAL-based sensible and latent heat fluxes in the irrigated Gediz Basin, Turkey. J. Hydrol. 2000, 229, 87-100. [CrossRef]

20. Tasumi, M.; Allen, R.G.; Trezza, R.; Wright, J.L. Satellite-Based energy balance to assess within-population variance of crop coefficient curves. J. Irrig. Drain. Eng. ASCE 2005, 1, 94-109. [CrossRef]

21. Tasumi, M.; Allen, R.G.; Trezza, R. At-surface reflectance and albedo from satellite for operational calculation of land surface energy balance. J. Hydrol. Eng. 2008, 2, 51-63. [CrossRef]

22. Teixeira, A.; Bastiaanssen, W.G.M.; Ahmad, M.D.; Bos, M.G. Reviewing SEBAL input parameters for assessing evapotranspiration and water productivity for the Low-Middle Sao Francisco River basin, Brazil Part A: Calibration and validation. Agric. For. Meteorol. 2009, 3-4, 462-476. [CrossRef] 
23. Allen, R.; Irmak, A.; Trezza, R.; Hendrickx, J.M.H.; Bastiaanssen, W.; Kjaersgaard, J. Satellite-based ET estimation in agriculture using SEBAL and METRIC. Hydrol. Process. 2011, 26, 4011-4027. [CrossRef]

24. Gowda, P.H.; Chávez, J.L.; Colaizzi, P.D.; Evett, S.R.; Howell, T.A.; Tolk, J.A. Remote sensing based energy balance algorithms for mapping ET: Current status and future challenges. Trans. ASABE 2007, 5, 1639-1644. [CrossRef]

25. Gowda, P.H.; Chávez, J.L.; Colaizzi, P.D.; Evett, S.R.; Howell, T.A.; Tolk, J.A. ET mapping for agricultural water management: Present status and challenges. Irrig. Sci. 2008, 26, 223-237. [CrossRef]

26. Elarab, M.; Ticlavilcab, A.; Torres-Ruab, A.; Maslovac, I.; McKeea, M. Estimating chlorophyll with thermal and broadband multispectralhigh resolution imagery from an unmanned aerial system using relevance vector machines for precision agriculture. Int. J. Appl. Earth Obs. Geoinf. 2015, 43, 32-42. [CrossRef]

27. Liaghat, S.; Balasundram, S.K. A review: The role of remote sensing in precision agriculture. Am. J. Agric. Biol. Sci. 2010, 5, 50-55. [CrossRef]

28. Berni, J.A.J.; Zarco-Tejada, P.J.; Suarez, L.; Fereres, E. Thermal and narrow-band multispectral remote rensing for vegetation monitoring from an unmanned aerial vehicle. IEEE Trans. Geosci. Remote Sens. 2009, 47, 722-738. [CrossRef]

29. Berni, J.A.J.; Zarco-Tejada, P.J.; Sepulcre-Cantó, G.; Fereres, E.; Villalobos, F. Mapping canopy conductance and CWSI in olive orchards using high resolution thermal remote sensing imagery. Remote Sens. Environ. 2009, 113, 2380-2388. [CrossRef]

30. Matese, A.; Toscano, P.; Filippo, S.; Gennaro, D.; Genesio, L.; Vaccari, F.P.; Primicerio, J.; Belli, C.; Zaldei, A.; Bianconi, R.; et al. Intercomparison of UAV, aircraft and satellite remote sensing platforms for precision viticulture. Remote Sens. 2015, 7, 2971-2990. [CrossRef]

31. Ortega-Farías, S.; López-Olivari, R. Validation of a two-layer model to estimate latent heat flux and evapotranspiration over a drip-irrigated olive orchard. Trans. ASABE 2012, 4, 1169-1178. [CrossRef]

32. Webb, E.K.; Pearman, G.I.; Leuning, R. Correction of flux measurements for density effects due to heat and water vapour transfer. Q. J. R. Meteorol. Soc. 1980, 106, 85-100. [CrossRef]

33. Schotanus, P.; Nieuwstadt, F.T.M.; de Bruin, H.A.R. Temperature measurement with a sonic anemometer and its application to heat and moisture fluxes. Bound. Layer Meteorol. 1983, 26, 81-93. [CrossRef]

34. Wilczak, J.M.; Oncley, S.P.; Stage, S.A. Sonic anemometer tilt correction algorithms. Bound. Layer Meteorol. 2001, 99, 127-150. [CrossRef]

35. Ortega-Farias, S.; Poblete-Echeverría, C.; Brisson, N. Parameterization of a two layer model for estimating vineyard evapotranspiration using meteorological measurements. Agric. For. Meteorol. 2010, 150, 276-286. [CrossRef]

36. Er-Raki, S.; Chehbouni, A.; Hoedjes, J.C.B.; Ezzahar, J.; Duchemin, B.; Jacob, F. Improvement of FAO-56 method for olive orchards through sequential assimilation of thermal infrared-based estimates of ET. Agric. Water Manag. 2008, 95, 309-321. [CrossRef]

37. Martínez-Cob, A.; Faci, J.M. Evapotranspiration of an hedge-pruned olive orchard in semiarid area of NE Spain. Agric. Water Manag. 2010, 97, 410-418. [CrossRef]

38. Twine, T.E.; Kustas, W.P.; Norman, J.M.; Cook, D.R.; Houser, P.R.; Meyers, T.P.; Prueger, J.H.; Starks, P.J.; Wesely, M.L. Correcting eddy covariance flux underestimates over a grassland. Agric. For. Meteorol. 2000, 103, 279-300. [CrossRef]

39. Goward, S.N.; Markham, B.; Dye, D.G.; Dulaney, W.; Yang, J.L. Normalized difference vegetation index measurements from the advanced very high-resolution radiometer. Remote Sens. Environ. 1991, 35, 257-277. [CrossRef]

40. Rouse, J.W.; Haas, R.H.; Schell, J.A.; Deering, D.W. Monitoring vegetation systems in the Great Plains with ERTS. Third ERTS Symposium; Freden, S.C., Becker, M.A., Eds.; NASA Goddard Space Flight Center: Greenbelt, MD, USA, 1973; pp. 309-317.

41. Zarco-Tejada, P.J.; Gonzalez-Dugo, V.; Berni, J.A.J. Fluorescence, temperature and narrowband indices acquired from a UAV platform for water stress detection using a micro-hyperspectral imager and a thermal camera. Remote Sens. Environ. 2012, 117, 322-337. [CrossRef]

42. Corcóles, J.I.; Jose, F.; Ortega, J.F.; Hernández, D.; Moreno, M.A. Estimation of leaf area index in onion (Allium cepa L.) using an unmanned aerial vehicle. Biosyst. Eng. 2013, 115, 31-42. [CrossRef]

43. Sanchez, J.M.; Lopez-Urrea, R.; Rubio, E.; Caselles, V. Determining water use of sorghum from two-source energy balance and radiometric temperatures. Hydrol. Earth Syst. Sci. 2011, 15, 3061-3070. [CrossRef] 
44. Sánchez, J.M.; López-Urreab, R.; Rubioc, E.; González-Piquerasd, J.; Caselles, V. Assessing crop coefficients of sunflower and canola using two-source energy balance and thermal radiometry. Agric. Water Manag. 2014, 137, 23-29. [CrossRef]

45. Kustas, W.P.; Alfieri, J.G.; Anderson, M.C.; Colaizzi, P.D.; Prueger, J.H.; Evett, S.R.; Neale, C.; French, A.; Hipps, L.E.; Chávez, J.L.; et al. Evaluating the two-source energy balance model using local thermal and surface flux observations in a strongly advective irrigated agricultural area. Adv. Water Resour. 2012, 50, 120-133. [CrossRef]

46. Poblete-Echeverría, C.; Ortega-Farias, S. Parameterization of surface energy balance components over a drip-irrigated Merlot vineyard using reflectance and meteorological data. Irrig. Sci. 2012, 30, 485-497.

47. Long, D.; Singh, V.P. A modified surface energy balance algorithm for land (M-SEBAL) based on a trapezoidal framework. Water Resour. Res. 2012, 48. [CrossRef]

48. Shuttleworth, W.J.; Wallace, J.S. Evaporation from sparse crops-an energy combination theory. Q. J. R. Met. Soc. 1985, 111, 839-855. [CrossRef]

49. López-Olivari, R.; Ortega-Farías, S.; Morales, L.; Valdés, H. Evaluation of three semi-empirical approaches to estimate the net radiation over a drip-irrigated olive orchard. Chil. J. Agric. Res. 2015, 75, 341-349. [CrossRef]

50. Gonzalez-Dugo, V.; Zarco-Tejada, P.; Berni, J.A.J.; Suárez, L.; Goldhamer, D.; Fereres, E. Almond tree canopy temperature reveals intra-crown variability that is water stress-dependent. Agric. For. Meteorol. 2012, 154-155, 156-165. [CrossRef]

51. Willmott, C.J. On the validation of models. Phys. Geogr. 1981, 2, 184-194.

52. Mayer, D.G.; Butler, D.G. Statistical validation. Ecol. Model. 1993, 1-2, 21-31. [CrossRef]

53. Fernandes-Silva, A.A.; Ferreira, T.C.; Correia, C.M.; Malheiro, A.C.; Villalobos, F.J. Influence of different irrigation regimes on crop yield and water use efficiency of olive. Plant Soil 2010, 333, 35-47. [CrossRef]

54. Ezzahar, J.; Chehbouni, A.; Hoedjes, J.C.B.; Er-raki, S.; Chehbouni, A.H.; Bonnefond, J.M.; De Bruin, H.A.R. The use of the scintillation technique for estimating and monitoring water consumption of olive orchards in a semi-arid region. Agric. Water Manag. 2007, 89, 173-184. [CrossRef]

55. Er-Raki, S.; Chehbouni, A.; Boulet, G.; Williams, D.G. Using the dual approach of FAO56 for partitioning ET into soil and plant components for olive orchards in a semiarid region. Agric. Water Manag. 2010, 97, 1769-1778. [CrossRef]

56. Villalobos, F.J.; Orgaz, F.; Testi, L.; Federes, E. Measurement and modeling of evapotranspiration of olive (Olea europaea L.) orchards. Eur. J. Agron. 2000, 13, 155-163. [CrossRef]

57. Testi, L.; Orgaz, F.; Villalobos, F.J. Variations in bulk canopy conductance of an irrigated olive (Olea europaea L.) orchard. Environ. Exp. Bot. 2006, 55, 15-28. [CrossRef]

58. Lee, X.; Black, T.A. Atmospheric turbulence within and above a douglas-fir stand. Part II. Eddy fluxes of sensible heat and water vapour. Bound. Layer Meteorol. 1993, 64, 369-389. [CrossRef]

59. Wilson, K.; Goldstein, A.; Falge, E.; Aubinet, M.; Baldocchi, D.; Berbigier, P.; Bernhofer, C.; Ceulemans, R.; Dolman, H.; Field, C.; et al. Energy balance closure at FLUXNET sites. Agric. For. Meteorol. 2002, 113, 223-243. [CrossRef]

60. Leuning, R.; van Gorsel, E.; Massman, W.J.; Isaac, P.R. Reflections on the surface energy imbalance problem. Agric. For. Meteorol. 2012, 156, 65-74. [CrossRef]

61. Williams, D.G.; Cable, W.; Hultine, K.; Hoedjes, J.C.B.; Yepez, E.A.; Simonneaux, V.; Er-Raki, S.; Boulet, G.; de Bruin, H.A.R.; Chehbouni, A.; et al. Evapotranspiration components determined by stable isotope, sap flow and eddy covariance techniques. Agric. For. Meteorol. 2004, 125, 241-258. [CrossRef]

62. Testi, L.; Villalobos, F.J.; Orgaz, F. Evapotranspiration of a young irrigated olive orchard in southern Spain. Agric. For. Meteorol. 2004, 121, 1-18. [CrossRef]

63. Foken, T. The energy balance closure problem: An overview. Ecol. Appl. 2008, 18, 1351-1367. [CrossRef] [PubMed]

64. Chávez, J.; Gowda, P.; Howell, T.; Neale, C.; Copeland, K. Estimating hourly crop ET using a two-source energy balance model and multispectral airborne imagery. Irrig. Sci. 2009, 28, 79-91. [CrossRef]

65. Jusoff, K. Evaluation of spatial variability of soil in an oil palm plantation. In Proceedings of the ISCO 2004-13th International Soil Conservation Organization Conference, Brisbane, Australia, 4-8 July 2004.

66. Liu, S.; Lu, L.; Mao, D.; Jia, L. Evaluating parameterizations of aerodynamic resistance to heat transfer using field measurements. Hydrol. Earth Syst. Sci. 2007, 11, 769-783. [CrossRef] 
67. Ortega-Farias, S.; Aguilar, R.; De la Fuente, D.; Ortega-Salaza, S.; Fuentes, F. Evaluation of a model to estimate net radiation over a drip-irrigated olive orchard using Landsat satellite images. Acta Hortic. (ISHS) 2014, 1057, 309-314. [CrossRef]

68. Shaomin, L.; Guang, H.; Li, L.; Defa, M. Estimation of regional evapotranspiration by TM/ETM+ data over heterogeneous surfaces. Am. Soc. Photogramm. Remote Sens. 2007, 73, 1169-1178.

69. González-Dugo, M.P.; González-Piqueras, J.; Campos, I.; Andréu, A.; Balbontín, C.; Calera, A. Evapotranspiration monitoring in a vineyard using satellite-based thermal remote sensing. SPIE Proc. 2012, 8531, 272-288.

70. Ortega-Farias, S.; Aguilar, R.; De la Fuente, D.; Ortega-Salaza, S.; Fuentes, F.; Poblete-Echeverría, C. Estimation of evapotranspiration for a drip-irrigated olive orchard using multispectral satellite images. In Proceedings of the USCID Fourth International Conference on Irrigation and Drainage, Using 21st Century Technology to Better Manage Irrigation Water Supplies, Phoenix, AZ, USA, 16-19 April 2013.

71. Xia, T.; Kustas, W.P.; Anderson, M.C.; Alfieri, J.G.; Gao, F.; McKee, L.; Prueger, J.H.; Geli, H.; Neale, C.M.U.; Sanchez, L.; et al. Mapping evapotranspiration with high-resolution aircraft imagery over vineyards using one- and two-source modeling schemes. Hydrol. Earth Syst. Sci. 2016, 20, 1523-1545. [CrossRef]

72. Homann, H.; Nieto, H.; Jensen, R.; Guzinski, R.; Zarco-Tejada, P.J.; Friborg, T. Estimating evaporation with thermal UAV data and two-source energy balance models. Hydrol. Earth Syst. Sci. 2016, 20, 697-713. [CrossRef]

(C) 2016 by the authors; licensee MDPI, Basel, Switzerland. This article is an open access article distributed under the terms and conditions of the Creative Commons Attribution (CC-BY) license (http:/ / creativecommons.org/licenses/by/4.0/). 